\title{
EVALUATION OF ONLINE PRACTICAL LEARNING FOR LIGHT AUTOMOTIVE ENGINEERING DURING THE COVID-19 PANDEMIC
}

\author{
Mochammad Baharudin Siddiq ${ }^{1, ~}$, Zainal Arifin², Putu Sudira ${ }^{3}$, Farid Mutohhari ${ }^{4}$ \\ 1,3,4Postgraduate Program of Technology and Vocational Education, Universitas Negeri Yogyakarta, Karangmalang, \\ Yogyakarta 55281, Indonesia \\ ${ }^{2}$ Department of Automotive Engineering Education, Universitas Negeri Yogyakarta, Karangmalang, Yogyakarta 55281, \\ Indonesia \\ E-mail: baharudinsiddiq@gmail.com * \\ *Corresponding Author
}

\begin{abstract}
Vocational education is characterized by practical learning. During online learning in the Covid-19 outbreak, students' practice learning outcomes have decreased significantly. This study evaluates the implementation of online practical learning in Vocational High Schools (VHS) for technical competencies of Light Automotive Engineering in terms of Context, Input, Process, and Product (CIPP). This study was conducted at a Vocational High School, SMKN 1 Simpangkatis, Central Bangka Regency. The research subjects were the principal, vice-principal, 5 productive teachers, and 191 students in the department of Light Automotive Engineering. This evaluation research used the CIPP method. Data were collected through questionnaires supported with interviews and documentation. The findings indicated that (1) the implementation of online practical learning for context and input components is included in the medium category and (2) the process and product components are categorized as low.
\end{abstract}

Keywords: CIPP, evaluation, online practical learning, technical skills

\section{INTRODUCTION}

Vocational education has a mission as one of the human resource development institutions of a country [1], [2]. Where, work competencies that include cognitive, affective, and psychomotor domains are provided through learning [3]. The achievement of graduate work competencies in these three domains is an indicator of the success of vocational education [4]. The three domains of work competence are pursued through learning both theoretically and practically. In addition, understanding that is abstract and concrete in learning becomes a special characteristic in achieving work competence in vocational learning [5]. The complexity of the learning becomes a unit that must be organized and managed properly so that the success of vocational education can be sustainable [6].

The complexity of learning in vocational education is increasing along with the development of science and technology in the $21^{\text {st }}$ century [7]. Where, digitalization of technology in the industrial world is increasingly dominating, so that the disruption of old jobs also occurs [8], [9]. Problemsolving skills, creativity, critical thinking, teamwork, and digital technology are increasingly prioritized [10]-[14]. This is what adds to the complexity of vocational education, where 21st-century competencies must be taught through learning [15].

However, the basic problem that occurs in vocational education, especially in Indonesia is how to manage increasingly complex learning [16]. The success of vocational education is still a question mark that does not have a clear answer until now. Various important notes related to problems in vocational education have been revealed. The absorption of graduates in the industrial world is an important indicator that shows problems in vocational learning [17]. The absorption of vocational education graduates in Indonesia is still in the lowest category than graduates from other types of education [18]. The low work competence of graduates is the biggest 
contributor to the non-absorption of graduates in the industrial world [19]. In addition, graduates' work readiness and interest are also a problem in vocational education [20].

These issues arise as a result of problems experienced during the learning process. The lack of learning orientation with the current and future competency needs of the industrial world is the main factor in the problem of competence, work readiness, and low interest in work [21]. Another problem arises from the lack of interactive learning which results in low learning motivation [22]. This also causes low student competence due to a lack of learning motivation [23]. In addition, the integration of technology that is following current developments into learning is a problem that causes the competence of graduates to be less able to adapt to changes in the industrial world that occur [24], [25].

The problems above are even further exacerbated by the presence of the Covid-19 pandemic. Learning that originally took place face-to-face has been changed to online learning using the internet network. This of course greatly affects the learning process and also student learning outcomes [26]. Several studies have noted that there has been a significant decrease in student learning outcomes during online learning amid the Covid-19 widespread [27]. Moreover, in vocational education which has the characteristic of practical learning to strengthen students' hands-on skills, the decline is more significant than others. This is because practical learning requires face-to-face contact with the support of adequate facilities and infrastructure [28].

One of the majors in vocational education in Indonesia that was affected by the Covid-19 pandemic is the Light Automotive Engineering department. Crucial obstacles are faced by both students and teachers, especially when carrying out learning with practical basic competencies [29]. The limited tools and training objects owned by students are the biggest obstacle in the automotive department. In addition, the limited experience of teachers in managing practical learning during the pandemic is also an inhibiting factor [30].

This problem certainly cannot be allowed to drag on without a solution to the problem. Various solution steps continue to be developed to overcome various problems that occur in vocational education in Indonesia. Revitalization is the spearhead in overhauling learning management mechanisms in vocational education [31], [32]. The development of models, media, and learning resources continue to be carried out to support the practical learning process during the pandemic [33]. However, some of these steps have not seen significant positive results [19]. Thus, it is very important to conduct an indepth analysis of the learning that has been carried out during the Covid-19 pandemic [34]. Needs analysis related to the improvement of the learning process is the most important step to determine the right solution [35]. Thus, evaluation of practical learning is very important to do. The purpose of this study was to evaluate practical learning in the Light Automotive Engineering department during the Covid-19 pandemic.

\section{METHOD}

This study is evaluation research using quantitative research methods and evaluation models of Context, Input, Process, and Product (CIPP). It was conducted at a Vocational High School, SMKN 1 Simpangkatis, Central Bangka Regency. The research subjects were 1 principal, 1 curriculum vice-principal, 5 productive teachers, and 191 students from the Light Automotive Engineering department.

Collecting data was through the distribution of questionnaires to respondents equipped with observations, interviews, and documentation. The questionnaire consisted of 62 questions for teachers and 52 questions for students related to online practical learning. The instrument used a score level of 1 (very low) to 4 (very high). Data analysis used the average analysis of each component. The validity was assessed through factor analysis 
where all items of the statement instrument were declared to be valid. Cronbach's alpha was used in the reliability test. The results of the instrument reliability test indicated that all items of the instrument were reliable. There were five assessment criteria adopted from Azwar [36] listed in Table 1. Interviews and documentation were also used to strengthen the results of the questionnaire.

Table 1. Assessment Criteria Score

\begin{tabular}{ccc}
\hline Formula & $\begin{array}{c}\text { Score } \\
\text { Interval }\end{array}$ & Category \\
\hline $\mathrm{X} \leq \mu-1.5 \alpha$ & $\leq 2.1$ & Very Low \\
$\mu-1.5 \alpha<\mathrm{X} \leq \mu-0.5 \alpha$ & $>2.1$ to 2.7 & Low \\
$\mu-0.5 \alpha<\mathrm{X} \leq \mu+0.5 \alpha$ & $>2.7$ to 3.3 & Average \\
$\mu+0.5 \alpha<\mathrm{X} \leq \mu+1.5 \alpha$ & $>3.3$ to 3.9 & High \\
\hline
\end{tabular}

\section{RESULTS AND DISCUSSION}

The context indicator relates to the condition of the school and the policy basis which consists of (1) the school's vision and mission; (2) government policies on online learning; (3) school policies on online learning; (4) the educational programs utilized as a reference within the usage of online learning. The results of the context evaluation are presented in Table 2. Table 2 shows that the context components have an average score of 3.00. The context in which online practice learning is being implemented falls within the average category. The evaluation showed that school policies and conditions in the implementation of online practical learning must be implemented. Based on observations, it was discovered that Vocational High School students must be prepared to implement this program in general. The implementation of online practical learning is fairly good but not optimal, according to the context evaluation.

Table 2. Context Component Quality Achievement Score

\begin{tabular}{ccccc}
\hline No & $\begin{array}{c}\text { Sub } \\
\text { Component }\end{array}$ & $\begin{array}{c}\text { Average } \\
\text { per } \\
\text { Aspect }\end{array}$ & $\begin{array}{c}\text { Average } \\
\text { components }\end{array}$ & Category \\
\hline \multirow{4}{*}{$\begin{array}{c}\text { School } \\
\text { Conditions } \\
\text { and Policy } \\
\text { Base }\end{array}$} & 3.00 & 3.00 & Average \\
\hline
\end{tabular}

The next indicator is the input indicator, which relates to (1) availability of facilities and infrastructure, which consists of (a) online learning platform, (b) ease of platform used in online learning, (c) availability of online learning books (e-books), (d) availability of online practical learning materials/modules, (e) availability of online learning media/ practice learning videos, (f) availability of online practice worksheets, $(\mathrm{g})$ availability of practical tools through online learning, (h) availability of learning resources (libraries) through online learning, (i) availability of practical workshops; (2) human resources consisting of (a) teacher educational background, (b) the experience of teaching teachers through online, (c) expertise competence of teachers, (d) student background, (e) student learning experience; (3) planning of practical learning programs in schools consisting of (a) availability of curriculum, (b) availability of practical learning syllabus, (c) availability of online lesson plans for practical learning, (d) job sheet/ lab sheet, (e) availability of teacher administration, (f) availability of student practice schedule. Table 3 summarizes the findings of the input evaluation. The input components in Table 3 have an average score of 3.11. The input for the implementation of online practical learning is in the average category.

Table 3. Input Component Quality Achievement Score

\begin{tabular}{ccccc}
\hline No & $\begin{array}{c}\text { Sub } \\
\text { Component }\end{array}$ & $\begin{array}{c}\text { Average } \\
\text { per Aspect components }\end{array}$ & $\begin{array}{c}\text { Average } \\
\text { Category }\end{array}$ \\
\hline 1 & $\begin{array}{c}\text { Facilities and } \\
\text { Infrastructure }\end{array}$ & 3.14 & & \\
2 & $\begin{array}{c}\text { Human } \\
\text { Resources } \\
\text { Learning } \\
3\end{array}$ & 2.93 & 3.11 & Average \\
& $\begin{array}{c}\text { Program } \\
\text { Planning }\end{array}$ & 3.26 & & \\
\hline
\end{tabular}

The obstacle is that the school has not provided accessible practicum equipment and materials used in online practical learning, and students are not yet prepared to create and assess practicum activities. As a consequence, it is expected that schools will completely 
support infrastructure for online practical learning to succeed.

The process indicator relates to the implementation of the practical learning program which consists of (a) virtual/ online module, (b) administration of the implementation of practical learning through online, (c) the learning materials delivered, (d) the suitability of the learning video, (e) steps for practical learning through online, (f) implementation of student practice, (g) structured assignments and independent assignments, (h) use of student practice equipment, (i) place of implementation of student practice, $(\mathrm{j})$ implementation of practical learning assessment, (k) implementation of skill competency test, (l) evaluation, (m) implementation of enrichment and improvement (remedies), (n) student attendance, and (o) student activity.

The results of the process evaluation are presented in Table 4. The process components have a 2.64 average score. The implementation of online practical learning is categorized as low. According to these criteria, there are still several obstacles to overcome in the implementation of online practical learning. The problem is that students find it difficult to practice directly because of the limitations of the tools and practice materials carried out. In addition, the presence and activity of students are also not like face-to-face learning activities. Teachers do more enrichment and remedial. Practice exam results also obtained low results.

\begin{tabular}{|c|c|c|c|c|}
\hline No & Sub Component & $\begin{array}{c}\text { Average } \\
\text { per } \\
\text { Aspect }\end{array}$ & $\begin{array}{l}\text { Average } \\
\text { components }\end{array}$ & Category \\
\hline 1 & $\begin{array}{l}\text { Implementation } \\
\text { of Learning } \\
\text { Program }\end{array}$ & 2.64 & 2.64 & Low \\
\hline
\end{tabular}

The product indicator relates to (1) students' practical learning outcomes in schools consisting of (a) the results of the assessment of student work practices, and (b) the results of the final practice assessment (Expertise
Competency Test); (2) hard skills and soft skills possessed by students, consisting of (a) what practical materials are obtained by online learning students, (b) the advantages and disadvantages of online practical learning, (c) the skills students acquire from online practical learning, (d) soft skills (attitude, discipline, and teamwork).

The results of the product evaluation are presented in Table 5. The average score of the product components in Table 5 is 2.47 . The product of the implementation of online practical learning is in a low category.

Table 5. Product Component Quality Achievement Score

\begin{tabular}{ccccc}
\hline No & $\begin{array}{c}\text { Sub } \\
\text { Component }\end{array}$ & $\begin{array}{c}\text { Average } \\
\text { per } \\
\text { Aspect }\end{array}$ & $\begin{array}{c}\text { Average } \\
\text { components }\end{array}$ & Category \\
\hline \multirow{2}{*}{1} & $\begin{array}{c}\text { Practical } \\
\text { Learning } \\
\text { Results }\end{array}$ & 2.47 & 2.47 & Low \\
\hline
\end{tabular}

The process and product indicator relate to students' hard skills and soft skills consisting of (a) What practical materials are obtained by students through online learning, (b) the advantages and disadvantages of online practical learning, (c) the skills students acquire from online practical learning, and (d) soft skills (attitude, discipline, and teamwork). The achievement of the quality of the process and product components of student respondents is 2.92 and is included in the average category.

The results of the process and product evaluation with student respondents are presented in Table 6 . The average product component score in Table 6 is 2.92 in the medium category. During the Covid-19 pandemic, there was very little direct practical learning implemented. Practical exercises are only done to help students in grade 12 prepare for the skill competency exam. Almost all subjects should be implemented in practice, but cannot be implemented and are not replaced in the form of watching practical videos and other project assignments. For grades 10 and 11, there is just a theory test to assess practical learning. Table 7 summarizes the CIPP evaluation of online practical learning. 
Table 6. Process and Product Component Quality Achievement Score

\begin{tabular}{lllll}
\hline No & \multicolumn{1}{c}{$\begin{array}{c}\text { Sub } \\
\text { Component }\end{array}$} & $\begin{array}{c}\text { Average } \\
\text { per } \\
\text { Aspect }\end{array}$ & $\begin{array}{c}\text { Average } \\
\text { components }\end{array}$ & Category \\
\hline 1 & $\begin{array}{l}\text { Practical } \\
\text { Learning } \\
\text { Results }\end{array}$ & 2.92 & 2.92 & Average \\
\hline
\end{tabular}

Table 7. Summary of CIPP Evaluation

\begin{tabular}{cccc}
\hline No & Aspect & $\begin{array}{c}\text { Average Components } \\
\text { Evaluations }\end{array}$ & Category \\
\hline 1 & Context & 3.00 & Average \\
2 & Input & 3.11 & Average \\
3 & Process & 2.64 & Low \\
4 & Product & 2.47 & Low \\
& Process & & \\
& and & 2.92 & Average \\
& Product & & \\
& (Student) & & \\
\hline
\end{tabular}

Previous studies focused on the advantages and disadvantages of online learning but it has not addressed the basic mastery of practice (technical skills) that can be accomplished online. Learning programs in the network (online) need to be studied further on the impact of students' technical mastery, especially the competence of Light Automotive Engineering skills that require practice.

Several studies have been conducted [37], [38] that show online learning model platforms are widely used, but there are weaknesses in mastering skills. Learning strategy applied by the teacher in the practicum session is through video tutorials [39], while practical learning should still require face-toface classes [40].

Practicum plays an important role in learning, especially for simulations in understanding scientific concepts [41]. Practicum amid the Covid-19 widespread must still be carried out as a space to sharpen students' logical abilities. Practicum also makes students not easily bored in the learning process [42]. The impact that occurs when practical activities are eliminated is the decline in students' skills in using various kinds of practical equipment and students' experience in conducting experiments and research [43]. Guidelines for effective online learning recognized that school learning change programs that utilize different shapes of innovation give positive results for understudies and instructors. Indeed so, numerous teachers are confronted with the challenge of how to facilitate practical learning in an online learning environment.

\section{CONCLUSION}

The implementation of online practical learning was evaluated from the context, namely online practical learning activities must indeed be carried out considering the ongoing pandemic, but the readiness was not optimal. The input evaluation was constrained by the problem of facilities and infrastructure, namely the tools and practicum materials used by students when practicing online. Process evaluation indicated many obstacles during implementation. Product evaluation showed that the learning outcomes were not achieved as expected. The form of online practicum learning using tools and materials that was easy to do and to obtain was mostly performed by most respondents. However, it was not feasible to do practicums that require large and complex practicum tools and materials. Some practices were still carried out in schools with strict health protocols. The main obstacle faced by students was the availability of tools and materials, especially if practicum materials and complex practicum materials were not available at home. The most optimal form of teacher explanation regarding practicum procedures was the use of a module book or practice guide accompanied by detailed explanations and practicum learning videos. Empowerment of practicum material resources that many students do not have prevents students from doing online practicum independently. Examples of forms of Light Automotive Engineering practice that can still be performed during the pandemic are video-based practicums practiced by teachers, making videos independently, analyzing the surrounding environment, looking for practice videos on the internet, then making practicum 
reports, to simple independent practice at home using borrowing tools from school.

\section{REFERENCES}

[1] C. Clarke, L., \& Winch, Vocational Education: International Approaches, Developments and Systems (1st ed.). Routledge, 2007.

[2] M. Pavlova, Technology and vocational education for sustainable development: Empowering individuals for the future. Springer Science \& Business Media, 2009.

[3] S. Billett, Vocational Education: Purposes, Traditions and Prospects [1 ed.], vol. 53, no. 9. 2011.

[4] M. Pilz, The Future of Vocational Education and Training in A Changing World. Wiesbaden: VS Verlag für Sozialwissenschaften, 2012.

[5] P. Sudira, TVET Abad XXI, 2nd ed. Yogyakarta: UNY Press, 2017.

[6] S. Soenarto, Sugito, Suyanta, Siswantoyo, and Marwanti, "Vocational and senior high school professional teachers in industry 4.0," Cakrawala Pendidik., vol. 39, no. 3, pp. 655-665, 2020, doi: 10.21831/cp.v39i3.32926.

[7] N. N. H. M. Salleh and S. Puteh, "A review of the 21 st century skills in technical vocational education and training (TVET)," Adv. Sci. Lett., vol. 23, no. 2, pp. 1225-1228, Feb. 2017, doi: $10.1166 /$ asl.2017.7546.

[8] C. Llopis-Albert, F. Rubio, and F. Valero, "Impact of digital transformation on the automotive industry," Technol. Forecast. Soc. Change, vol. 162, no. September 2020, p. 120343, 2021, doi: 10.1016/j.techfore.2020.120343.

[9] V. Tūtlys and G. Spöttl, "Disruption of qualifications in manufacturing: challenges and prospects," Eur. J. Train. Dev., vol. ahead-of-p, no. ahead-ofprint, Apr. 2021, doi: 10.1108/EJTD-072020-0121.
[10] G. Dogara, M. S. Bin Saud, Y. Bin Kamin, M. Z. B. A. Hamid, and M. S. Bin Nordin, "Developing soft skills through project-based learning in technical and vocational institutions," Int. J. Eng. Adv. Technol., vol. 9, no. 1, pp. 2842-2847, 2019, doi: 10.35940/ijeat.A9803.109119.

[11] D. Sulistyanto, S., Mutohhari, F., Kurniawan, A., \& Ratnawati, "Kebutuhan kompetensi dalam pasar tenaga kerja di era revolusi industri 4.0 bagi siswa SMK," J. Taman Vokasi, vol. 9, no. 1, pp. 1-13, 2021, doi: https://doi.org/10.30738/jtv.v9i1.7742.

[12] C. Sun, V. J. Shute, A. Stewart, J. Yonehiro, N. Duran, and S. D'Mello, "Towards a generalized competency model of collaborative problem solving," Comput. Educ., vol. 143, no. July 2019, p. 103672, 2020, doi: 10.1016/j.compedu.2019.103672.

[13] W. Wagiran, P. Pardjono, W. Suyanto, H. Sofyan, S. Soenarto, and A. Yudantoko, "Competencies of future vocational teachers: perspective of in service teachers and educational experts," J. Cakrawala Pendidik., vol. 38, no. 2, pp. 387-397, Jun. 2019, doi: 10.21831/cp.v38i2.25393.

[14] C. Zhou and A. Purushothaman, "The need to foster creativity and digital inclusion among women users in developing context - addressing second order digital divide in online skills," Int. J. Emerg. Technol. Learn., vol. 10, no. 3 , p. 69, Jun. 2015, doi: 10.3991/ijet.v10i3.4248.

[15] C. Trilling, B., \& Fadel, 21st Century Skills: Learning for Life In Our Times. Calif: John Wiley \& Sons., 2012.

[16] I. V Vaganova, O. I., Vezetiu, E. V, Vovk, E., Bulaeva, M. N., \& Akimova, "Technology of problem education in the training of vocational education teacher," Int. J. Innov. Technol. Explor. Eng., vol. 9, no. 3, pp. 127-129, Jan. 2020, doi: 
10.35940/ijitee.B6408.019320.

[17] M. K. Y. Hidayatuloh and S. Muslim, "Absorption level vocational high school graduates in industrial," J. Phys. Conf. Ser., vol. 1833, no. 1, 2021, doi: 10.1088/1742-6596/1833/1/012019.

[18] K. Afandi and B. Sentot Wijanarka, "Outcomes of vocational high schools in machining expertise in the labor market in Yogyakarta, Indonesia," Am. J. Educ. Res., vol. 7, no. 9, pp. 599-603, 2019, doi: 10.12691/education-7-9-1.

[19] C. R. Ridzwan, S. Malik, Z. Hanapi, S. Mohamed, M. A. Hussain, and S. Shahrudin, "Skills and knowledge competency of technical and vocational education and training graduate," Asian Soc. Sci., vol. 13, no. 4, p. 69, 2017, doi: 10.5539/ass.v13n4p69.

[20] R. Fenech, P. Baguant, and I. Abdelwahed, "Work readiness across various specializations," Acad. J. Interdiscip. Stud., vol. 9, no. 4, pp. 8692, 2020, doi: 10.36941/AJIS-20200064.

[21] J. Ifeoma Obidile, "Revitalization of the technical and vocational education (TVE) programmes for youth empowerment in Nigeria," Int. J. Vocat. Educ. Train. Res., vol. 4, no. $1, \quad$ p. $45, \quad 2018$, doi: 10.11648/j.ijvetr.20180401.17.

[22] M. Nurtanto, N. Kholifah, A. Masek, P. Sudira, and A. Samsudin, "Crucial problems in arranged the lesson plan of vocational teacher," Int. J. Eval. Res. Educ., vol. 10, no. 1, pp. 345-354, 2021, doi: 10.11591/ijere.v10i1.20604.

[23] H. Hariri, D. H. Karwan, E. Y. Haenilah, R. Rini, and U. Suparman, "Motivation and learning strategies: Student motivation affects student learning strategies," Eur. J. Educ. Res., vol. 10, no. 1, pp. 39-49, 2020, doi: 10.12973/EU-JER.10.1.39.

[24] M. Astuti, Z. Arifin, F. Mutohhari, and M. Nurtanto, "Competency of digital technology: the maturity levels of teachers and students in vocational education in Indonesia," $J$. Educ. Technol., vol. 5, no. 2, pp. 254-262, 2021, doi: $10.23887 /$ jet.v5i3.35108.

[25] F. Mutohhari, H. Sofyan, and M. Nurtanto, "Technological competencies: a study on the acceptance of digital technology on vocational teachers in Indonesia," 2021, doi: 10.4108/eai.6-32021.2305971 .

[26] F. Mutohhari, P. Sudira, and M. Nurtanto, "Automotive engineering drawing learning: effective online learning using autocad application," $J$. Educ. Technol., vol. 5, no. 2, pp. 214 219, 2021, doi: 10.23887/jet.v5i2.33197.

[27] Herwin, C. S. A. Jabar, A. Senen, and W. Wuryandani, "The evaluation of learning services during the covid-19 pandemic," Univers. J. Educ. Res., vol. 8, no. 11, pp. 5926-5933, 2020, doi: 10.13189/ujer.2020.082227.

[28] E. M. Onyema, "Impact of coronavirus pandemic on education," J. Educ. Pract., vol. 11, no. 13, pp. 108-121, 2020, doi: 10.7176/jep/11-13-12.

[29] W. Wagiran, D. Rahdiyanta, A. E. Wibowo, O. L. Sati, and M. R. Badu, "Online learning of mechanical engineering subject in the Covid-19 era: strategy, platform and media," J. Phys. Conf. Ser., vol. 1700, p. 012027, Dec. 2020, doi: 10.1088/17426596/1700/1/012027.

[30] Y. Estriyanto, S. Kersten, P. Pardjono, and H. Sofyan, "The missing productive vocational high school teacher competency standard in the Indonesian education system," J. Tech. Educ. Train., vol. 9, no. 1, pp. 26-44, 2017.

[31] C. C. Chinedu, W. A. Wan Mohamed, and A. O. Ajah, "A systematic review on education for sustainable development: Enhancing tve teacher training programme," J. Tech. Educ. Train., vol. 10, no. 1, pp. 109-125, 2018, doi: 
174 Jurnal Pendidikan Teknologi dan Kejuruan, Vol. 27, No. 2, October 2021 10.30880/jtet.2018.10.01.009.

[32] I. M. Sudana, "Revitalization of vocational high school roadmap to encounter the 4.0 industrial revolution," J. Soc. Sci. Res., vol. 5, no. 2, pp. 338-342, 2019, doi: 10.32861/jssr.52.338.342.

[33] R. Rabiman, P. Sudira, H. Sofyan, and M. Nurtanto, "Practical learning media in subject maintenance of chassis and power (MCP) based online: simple learning using videos on YouTube," Int. J. Interact. Mob. Technol., vol. 15, no. 03, p. 130,2021 , doi: 10.3991/ijim.v15i03.14943.

[34] M. M. Shafi, M. R. Neyestani, S. E. M. Jafari, and V. Taghvaei, "The quality improvement indicators of the curriculum at the technical and vocational higher education," Int. J. Instr., vol. 14, no. 1, pp. 65-84, 2020, doi: 10.29333/IJI.2021.1415A.

[35] A. L. Sylte, "Predicting the future competence needs in working life: Didactical implications for VET in Norway," Int. J. Res. Vocat. Educ. Train., vol. 7, no. 2, pp. 167-192, 2020, doi: 10.13152/IJRVET.7.2.3.

[36] S. Azwar, Preparing Psychological Scale. Yogyakarta: Pustaka Pelajar, 2012.

[37] K. Syauqi, S. Munadi, and M. B. Triyono, "Students' perceptions toward vocational education on online learning during the COVID-19 pandemic," Int. J. Eval. Res. Educ., vol. 9, no. 4, pp. 881-886, 2020, doi: 10.11591/ijere.v9i4.20766.

[38] H. Sofyan, F. D. Isnantyo, Fu'Adi, and A. Pratama, "Online learning model in the pandemic time COVID 19 at SMK Negeri 1 Saptosari Yogyakarta," J. Phys. Conf. Ser., vol. 1700, no. 1, 2020, doi: 10.1088/1742-6596/1700/1/012070.
W. Wagiran, D. Rahdiyanta, A. E. Wibowo, O. L. Sati, and M. R. Badu, "Online learning of mechanical engineering subject in the Covid-19 era : strategy, platform and media Online learning of mechanical engineering subject in the Covid-19 era: strategy, platform and media," J. Phys. Conf. Ser., 2020, doi: 10.1088/17426596/1700/1/012027.

[40] S. P. Gonçalves, M. J. Sousa, and F. S. Pereira, "Distance learning perceptions from higher education students- the case of Portugal," Educ. Sci., vol. 10, no. 12, pp. 1-15, 2020, doi: 10.3390/educsci10120374.

[41] C. D. Rahayu and S. B. Sartika, "Students learning motivation and concepts understanding of science through the use of PhET interactive simulations," SEJ (Science Educ. Journal), vol. 4, no. 1, pp. 63-76, 2020, doi: $10.21070 /$ sej.v4i1.750.

[42] S. Sugiharti and M. K. Sugandi, "Laboratorium virtual: media praktikum online untuk meningkatkan pemahaman siswa di masa pandemi," in Prosiding Seminar Nasional Pendidian 2: Transformasi Pendidikan sebagai Upaya Mewujudkan Sustainable Development Goals (SDCs) di Era Society 5.0, pp. 45-51, 2020.

[43] N. L. P. Ananda Saraswati and I. N. E. Mertayasa, "Pembelajaran praktikum kimia pada masa pandemi Covid-19: qualitative content analysis kecenderungan pemanfaatan teknologi daring," Wahana Mat. dan Sains J. Mat. Sains, dan Pembelajaran., vol. 14, no. 2, pp. 144-161, 2020. 